\title{
A qualitative Study of Accessibility Health Services among Communities on Small Islands in Makassar City
}

\author{
Alfiah Ramadhani Amran', Muhammad Alwy Arifin², Muhammad Syafar \\ ${ }^{1}$ Postgraduate Students, Administration and Health Policy, Faculty of Public Health, Hasanuddin University, \\ Makassar, Indonesia, ${ }^{2}$ Department of Health Administration and Policy, Faculty of Public Health, Hasanuddin \\ University, Makassar, Indonesia, ${ }^{3}$ Department of Health Promotion and Behavioral Sciences, Faculty of Public \\ Health, Hasanuddin University, Makassar, Indonesia
}

\begin{abstract}
This study aims to explore barriers to access in health services among small islands in Makassar City.

This research is qualitative research through content analysis by observing phenomena that occur based on the accessibility framework of Levesque, et.al. Data collection was carried out through in-depth interviews with 8 key informants and 9 other informants $(n=17)$.

This study found that geographical factors (distance, travel time, and transportation costs) were the main considerations in utilizing primary health services in the small island communities around Makassar City which were predominantly fishermen. The two closest islands (Barrang Caddi and Bone Tambung), have enjoyed easy access and free service for Universal Health Coverage (UHC) achievements.

It is different from the outer islands, especially Langkai and Lanjukang, although most of the residents already have National Health Insurance (NHI) they have difficulty using their cards due to geographical constraints. Moreover, fishermen often go fishing for days, becoming another obstacle in accessing quality health facilities available in Makassar City.

Various efforts have been made by the Makassar City Health Office to address the disparity in health services in the islands in Barrang Caddi, such as the use of sea ambulances, and regular visits. The marine ambulance is only one ship on standby between two public health centers in another village office if there is an emergency patient who must be referred to a hospital in Makassar City.

This disparity in access to health services triggers injustice among residents of the islands in the Makassar City area. Very contractual with the slogan: "Makassar City of the World".

This study revealed a special transportation need in the form of a very simple capacity sea ambulance and managed by island community communities that are not reached by sea ambulances from the public health center.
\end{abstract}

Keywords: access barriers, small islands, marine ambulance, five dimensions Levesque, Makassar city.

\section{Introduction}

In the last decade, Makassar was introduced as a 'world city', increasing the cooperation of various countries (sister cities) including waste management, creative industry development, human resource capacity building, and tourism sector development cooperation.
Makassar City is an old city in eastern Indonesia, as a center for transit and education trade. Makassar City has 12 small inhabited islands stretching along the urban coastline as part of the 210 Spermonde islands in the Makassar Strait.

Most of the population lives on the coast and islands, then known as coastal communities. Most of the island's 
coastal population is looking to work as a fisherman, depending on the season. ${ }^{1}$

Since the launch of the Universal Health Coverage (UHC) program in Indonesia, most of the population has been able to access the available health services. ${ }^{2,3}$. In Makassar City, the coverage of National Health Insurance (NHI) membership reached 80 percent. Nevertheless, there are still imbalances in health services, especially residents who live on the outer islands of Makassar City. Even among the islands, there are still those who do not yet have health service facilities such as the Supporting Community Health Centers (Pustu).

This study aims to explore the accessibility of health services in the small island communities in Makassar based on the concept of accessibility of Levesque, et.al. includes five dimensions of accessibility including dimensions of approachability, acceptability, availability and accommodation, affordability, and appropriateness to have health services needs fulfilled. ${ }^{4}$

\section{Materials and Method}

This research is qualitative research through content analysis by observing phenomena that occur based on 5 dimensions of accessibility from Levesque, et.al. Data collection was carried out through in-depth interviews with 8 key informants and 9 other informants $(n=17)$.

The design is considered following this study which aims to explore the 5 dimensions of accessibility based on Levesque, et.al ${ }^{4}$ including dimensions of approachability, acceptability, availability and accommodation, affordability, and appropriateness to have health services needs fulfilled.

Data collection was carried out through in-depth interviews with 8 key informants who were deemed to meet the competencies to be studied and 9 other informants ( $n=17$ ) as having used or were currently using available health services.

Data analysis uses content analysis to analyze the phenomena found in this study.

\section{Results}

This research explores 5 dimensions of health service accessibility according to Levesque, et.al. [3] includes dimensions of closeness (approachability), acceptance (availability ability), availability (availability and accommodation), the ability of users (affordability), and appropriateness to enjoy quality, equal and affordable health services to small island communities on the coast of Makassar City.

\section{The dimension of Proximity (approachability)}

The proximity dimension covers geographical aspects (distance traveled, travel time, and transportation costs), and health insurance coverage (JKN / KIS)

Distance to health services in Makassar City, between 11 - $46 \mathrm{~km}$, the closest is Barrang Caddi Island and the farthest is Lanjukang Island.

As an example :

"The distance to the nearest island is about $11 \mathrm{~km}$, and the outermost island is around $46.5 \mathrm{~km}$ " (IS, 51 years)

Travel time between 30 minutes to 4 hours.

"The travel time to Bone Tambung Island and Barrang Caddi is around 30-45 minutes. Whereas to the outer islands around 4 hours, if the weather is good. (KS, 39 years)

Traveled using a 40 PK outboard motorboat with a capacity of 30 passengers, or a rented lifeboat.

As an example :

"Generally passengers use wooden boats carrying 30 people, with rent of Rp. 15,000, - one way to the nearest island. While the outer islands do not yet have public transportation, if you do not have your boat you have to rent a special around Rp. 250,000 - one way "(GSS, 46 years)

It is different if only using the available health facilities on the island in the form of a Puskemas Assistant (Pustu), the location is in the middle of a settlement, so there are no obstacles.

In the region of Barrang Caddi, holders of the Healthy Indonesia Card (KIS) as proof of the National Health Insurance (JKN), still around 70-80 percent have it. 
As an example :

"Coverage of health insurance coverage has not been exhaustive, only about 70-80\% have in the Barrang Caddi Village. (MB, 45 years)

\section{Acceptability dimensions}

The acceptability dimension includes perceptions of service quality and discrimination in health services for vulnerable groups

3. Service Quality Perception

As an example :

“ Public Health Center Assistant (Pustu) is very petrified within the community fulfilment of health services there are also Integrated Service Post (Posyandu) which every month weighing babies. " (IS, 50 years old)

\section{b. Discrimination Services}

As an example :

"Nothing, everything is served by both the rich and the poor National Health Insruance (NHI) members or Social Security Agency of Health (SSAH) Independent." (IS, 50 years)

3. Dimensions of Availability (availability and accommodation)

The availability and accommodation dimensions include infrastructure, health equipment, pharmaceuticals (medicines), and health workforce resources.

a. Infrastructure

As an example :

"The health service infrastructure already exists but is not sufficient enough, it still needs to be equipped so that the quality of service is adequate. Another problem, if there are emergency patients who must be referred to the Public Health Center or Hospital in Makassar City, there is no medical transportation available. (AR, 43 years old)

b. Medical tools

As an example :
"It is said to be adequate, not much is lacking, but there is still something that can be used by medical personnel here. (MB, 45 years old)

c. Pharmacy (medicine)

As an example :

"It's still very lacking because the Pustu still sometimes lacks the medicine here" (MU, 37 years)

d. Health personnel resources

As an example :

"The available HR for health workers is not sufficient due to the lack of interest of health workers to be placed on the coast, so currently they only rely on human resources for health workers who live on the island." (MS, 39 years old)

\section{Dimensions of user capability (affordability)}

The dimensions of user affordability include the description of community work and the level of income.

a. Job description

As an example :

"The work of the community is around 80\% anglers, $10 \%$ traders, approximately $9 \%$ work in the city, and approximately $1 \%$ government employees. (MSB, 39 years old)

5. The appropriateness dimension

Dimensions of service suitability (appropriateness) in the form of the appropriateness of requests with services received, and perceptions of services provided following the provider.

a. Appropriate requests with services received

As an example :

"The health services provided are as requested when the community comes for treatment at the Pustu. Many withered patients (decompressors) who are unable to be treated by a Pustu, must be referred to the hospital. Sometimes patients get frustrated because their illnesses don't heal and medical treatment costs are expensive, eventually resigned. "(MSB, 51 years old) 
b. Perception of services provided following the provider

As an example :

"We do not open certain hours for examinations, patients can come to the Pustu at any time when they need health care. Both in terms of schedule and time of health workers never provide limits to the community. " (HA, 33 years old)

\section{Discussion}

This study revealed that since the implementation of the Universal Health Coverage (UHC) program in Indonesia since 2014, the majority of Indonesia's population has been covered by the national health insurance system (NHI) and has enjoyed the available health services ${ }^{2 ; 3}$. In Makassar City, about 80 percent of the fishing communities in the five groups of Barrang Caddi Island have owned National Health Insurance (NHI) as Recipients of Contribution Aid (PBI) for the poor and disadvantaged groups since 2014 .

Nevertheless, there are still residents who experience obstacles in accessing available health services due to geographical dimensions (distance, travel time, transport costs), and are not covered by National Health Insurance (NHI), as is the case in remote China. 5,6

The islands closest to Makassar City such as Barrang Caddi Island, the community can enjoy quality health services in Makassar City almost every day while shopping for their household needs or purchasing merchandise supplies. They have felt the impact of equality in accessing health services according to the UHC program. ${ }^{2,8}$

The results of research by Laksono A.D, et.al. shows that adults living in urban areas tend to use hospital outpatient facilities 1.3 times higher than adults living in rural areas. The likelihood of utilizing outpatient and inpatient facilities at the same time is 1.2 times higher in adults living in urban areas than in rural areas. ${ }^{10}$

Different conditions are felt for residents of the outer islands such as Langkai Island and Lanjukang Island in accessing available health services. The main obstacles in the form of geographical access (distance traveled, travel time, transport costs), including not yet covered by National Health Insurance (NHI). The outer islands such as Lanjukang Island have no health facilities at all, causing residents to have to cross to other nearby islands to get primary health care.

The fate of the inhabitants of the outer islands in Makassar City who generally work as fishermen is not as good as the rural population in Indonesia, where most of the low-income villagers have enjoyed the available health services. $3 ; 9$

Some residents prefer to become traditional divers fishermen chasing high-value species such as sea cucumbers, even though they know the risk is heavy. No wonder, if there are some traditional diver fishermen in the Barrang Caddi Island group found to suffer from decompressors (DCS) even at a young age. The same thing is found in sea cucumber fishermen on the Yucatan Peninsula, Mexico ${ }^{11}$ Prolonged treatment time and direct and indirect $\operatorname{costs}^{12}$, cause decompressor patients to become apathetic. Patients with decompressors (DCS) in Taiwan have a 3.8-fold risk of experiencing psychiatric disorders, and a 5.7 -fold risk of sleep disorders ${ }^{13}$.

Makassar's slogan "City of the World", feels bitter for a group of fishermen on the outer islands that are neglected. Urban and provincial health facilities even at the national level are available only for the inhabitants of the outer islands of the region.

Unfair access has hampered opportunities for outermost island patients to obtain appropriate health services based on their perception of care needs. This requires consideration not only of service availability but also the quality of care ${ }^{14-21}$.

The urgent need is to provide simple capacity marine ambulances on each island to transport emergency patients. As is the desire of the small island community to manage marine ambulances for emergency patients managed by the local fishing community. ${ }^{15-18}$ Speed up the coverage of National Health Insurance (NHI) membership for all residents of the small islands in the coastal city of Makassar in accordance with the mandate of Universal Health Coverage (UHC) so that there are no more populations that are not covered by national health insurance (NHI), especially the poor and poor. 


\section{Conclusions}

Around 80 percent of the people in the Barrang Caddi Island group has been covered by National Health Insurance (NHI) and are used to obtain the needed health services, especially fishing communities who live on islands closest to Makassar City such as Barrang Caddi Island.

There is still an imbalance in access to health services, especially in the outer islands of Makassar due to geographical constraints (distance, travel time, transportation costs), and lack of National Health Insurance (HHI).

The discovery of decompressor patients requires special attention to treatment efforts.

Ethical Clearance- Taken from university ethical committee

\section{Source of Funding- Self}

\section{Conflict of Interest - Nil}

\section{References}

1. Ginting B, Nasution Arif M, Subhilhar S, Harahap Hamdani R. Analysis of weaknesses of the coastal community economic empowerment program (PEMP) and the national program of community empowerment of independent marine and fisheries (PNPM-MKP) on traditional fishermen in Indonesia. Jr Sci Res. 2018; 4 (87762): 41-53.

2. Agustina, Rina et .al. (2019). Universal health coverage in Indonesia: concepts, progress, and challenges, The Lancet, Volume 393, Issue 10166, pages 1-102, e1-e2 (5-11 January 2019), https: // www. sciencedirect.com/journal/the-lancet/ vol/393/issue/10166

3. Widjaja FF. Universal health coverage in Indonesia - Forgotten prevention. Med J Indones. 2014; 23 (3): 63-.

4. Jean-Frederic Levesque, Mark F Harris, and Grant Russell. Patient-centered access to health care: conceptualizing access at the interfaces of health systems and populations, International Journal for Equity in Health 2013, 12:18.

5. Ruishan Hu, Suocheng Dong, Yonghong Zhao, Hao Hu, \& Zehong Li. Assessing Potential Spatial Accessibility of Health Services in Rural China:
A Case Study of Donghai County. International journal for equity in health, 2013; 12(1), 35.

6. Xie, X., Wu, Q., Hao, Y., Yin, H., Fu, W., Ning, N., . . . Kang, Z. Identifying Determinants of Socioeconomic Inequality in Health Service Utilization Among Patients with Chronic NonCommunicable Diseases in China. PloS one, 2014; 9(6).

7. Iqbal, Md. Hafiz, Disparities of health services for the poor in the coastal area: does Universal health coverage reduce disparities ?, Journal of Market Access \& Health Policy, 2019; 7 (1): 1575683.

8. Wiseman, et.al., An evaluation of health systems equity in Indonesia: study protocol, International Journal for Equity in Health volume 2018; 17, Article number: 138

9. Shihab AN, Nurdin A, Kadir A, Thabrany H, Paturusie I. Equity in the utilization of inpatient for the National Health Insurance (JKN) program in Indonesia. Int J Sci 2017; 31: 58-74.

10. Agung Dwi Laksono, Ratna Dwi Wulandari, Oedojo Soedirham, Urban and Rural Disparities in Hospital Utilization among Indonesian Adults, Iran J Public Health. 2019 Feb; 48 (2): 247-255.

11. Oswaldo Huchim-Lara, Walter Chin, Undersea \& hyperbaric medicine: journal of the Undersea and Hyperbaric Medical Society, Inc.2017; 44 (2)・12. K.Cairins, et.al., Cost-effectiveness and Safety of Interspinous Process Decompression (Superion), PainMed.2019 Dec; 20(Suppl 2): S2-S8.Published online 2019 Dec 6. doi: 10.1093/pm/pnz245

13. Tseng, et.al., Risk of Sleep Disorders in Patients With Decompression Sickness: A Nationwide, Population-Based Study in Taiwan, Psychiatria Danubina, 2018; Vol. xx, No.x, pp xxx-xxx, Medicinska naklada - Zagreb, Croatia.

14. ME Kruk, et.al. High-quality health systems in the Sustainable Development Goals era: time for a revolution, https://www.thelancet.com/action/ showPdf?pii=S2214-109X\%2818\% 2930 386-3

15. Razak, A, et.al. A Study on the Implementation of Universal Health Coverage Improvement in Coastal Communities in Selayar Islands Regency, South Sulawesi, Indonesia, International Journal of Psychosocial Rehabilitation, 2020; Vol. 24, Issue 0.7,

16. Iqbal, Md. Hafiz, Universal Health Coverage for the Poor in the Coastal Bangladesh training Ethics and 
Economics Responsibility, World Journal of Social Sciences Vol. 8. No 2. June 2018, Pp. 14-30.

17. Rosmala Nur, Siti Ika Fitrasyah, Anwar Mallongi, Women's Reactions and Health Disorders Caused by Abuse During the Pregnancy-Postpartum Period. Medico-legal Update, January-March 2020, Vol.20, No. 1

18. Birawida, A.B., Selomo, M., Mallongi, A. Potential hazards from hygiene, sanitation and bacterium of refill drinking water at Barrang Lompo island (water and food safety perspective) IOP Conference Series: Earth and Environmental Science 2018; Volume 157, Issue 1, Article number 012034

19. Russeng, S.S., Saleh, L.M., Virani, D., Latief, A.W.L., Mallongi, A. The investigation of the lactic acid change among employee of national electrical power plan. Indian Journal of Public Health Research and Development 2018; Volume 9, Issue 1, Pages 361-365

20. Rosmala Nur, Muh. Asep Dwitama, Muh. Fadly, Nurhaya S Patui, Sitti Radhiah, Elvaria Mantao, Anwar Mallongi,. The Culture and Age of First Marriage on Female Teenagers in West Marawola. Medico-legal Update, January-March 2020, Vol.20, No. 1

21. Anwar Mallongi, Stang, Syamsuar, Muh Fajaruddin Natsir, Ratna Dwi Puji Astuti, Annisa Utami Rauf, Muhammad Rachmat, Abdul Muhithd, Potential ecological risks of mercury contamination along communities area in tonasa cement industry Pangkep, Indonesia. Enfermería Clínica., Volume 30, Supplement 4, June 2020, Pages 119-122 